\title{
Evolution of regional development in context of ecological and economic security
}

\author{
Irina Dovbiy ${ }^{1, *}$ and Vlada Kobyljakova ${ }^{1}$ \\ ${ }^{1}$ South Ural State University (National Research University), 76, Lenina str., 454080, Chelyabinsk, \\ Russia
}

\begin{abstract}
The article describes the transformations taking place in the Russian regional economy. The research is based on the hypothesis that the regional economy develops according to the laws of cyclical development. The research is based on the theory of technologies and global economic structures of Yuri Glazyev. A special place is occupied by the identification of patterns of change in the phenomenon of region and the prediction of its institutional characteristics. The global economy is entering a new cycle of development driven by climate change. The place and role of the region as a special subject of economic relations is changing. The region's environmental and economic security becomes a condition for its competitiveness. The task was set and solved to analyze the main trends in the development of the ecological and economic security of the region, which can ensure the harmonization of interests of the regions and the federal center during the transition to a new technological structure. The authors formulated a conflict of interests caused by the state's development policy and the deterioration of the environment in the regions.
\end{abstract}

\section{Introduction}

The global economy is entering a new cycle of development driven by climate change. The place and role of the region as a special subject of economic relations is changing. The region is becoming a specific phenomenon of the global economy. The region's environmental and economic security becomes a condition for its competitiveness. At the same time, the contradiction between the interests of the federal center and the regions in terms of environmental and economic policy is growing. Ensuring the ecological and economic security of the Russian region in the context of the transition to a new technological structure is undoubtedly urgent. Research objectives and questions include: to identify the main features of the Russian region as a special economic phenomenon; to reveal the content of ecological and economic security in relation to the region; to disclose the problems, risks and threats to the ecological and economic security of the region in the context of a new reality (the transition of the global economy to the sixth technological structure).

\footnotetext{
* Corresponding author: dovbiiip@susu.ru
} 


\section{Materials and methods}

The research is based on the modern paradigm of regional development in combination with the concept of wavy cyclical civilizational development. The study is based on the hypothesis that the development of Russian regions is cyclical and the condition for sustainable development is environmental and economic security. This is due to the following reason.

The change in the technological structure will be accompanied by crisis phenomena until 2030 [11]. At the same time, Russian regions will have to meet the tasks of creating "green economy" towards a "post-carbon" society.

The issues of harmonization of economic relations at the level of countries and regions are widely considered by European authors in relation to the policy of the European Union [10].

P. Krugman identifies two groups of factors of economic development. Factors of the "first nature" are immobile factors of production (the resource availability and geographical location of the territory relative to markets, main trade routes, etc.) Factors of the "second nature" are self-reinforcing advantages the agglomeration effect, the concentration of human capital and institutions) [7].

D. Rodrik notes that spatial factors of production have a significant impact on economic growth and differentiation of countries' development. "Direct" (proximate) factors are endogenous factors of production (accumulation of physical and human capital) and productivity growth. The deep determinants of development are exogenous factors (institutions, trade, geography)) [12].

S.D. Bodrunov proves that «emergence of new technologies does not evidence the transition to services society, but weights in favour of the necessity of reindustrialization on a qualitatively new technological base, and this requires the domination of knowledge over material factors in all production economic processes» [2].

The new quality of the economic space is formed under the influence of factors of the coordinated and balanced development of territories [1].

Scientists note that Russian regions are characterized by varying degrees of spatial heterogeneity. The research results show that «it is impossible to use a single unified model for the development of different territories. It is necessary to apply a differentiated approach in determining the landmarks of spatial development» [8].

The analysis showed «that there is a movement of economic activity from the East to the West, from the "periphery» to the "center», and from the resource-rich to the manufacturing regions» [6].

Thus, spatial development acquires the features of an independent object of regulation. Regional policies should include social and climatic imperatives. The ecological and economic security of the region is becoming an important factor in the region's transition to the sixth technological structure.

In the course of the study, the authors used an abstract-logical method that provides theoretical generalizations and the formation of conclusions. We also applied general scientific methods of theoretical and empirical knowledge, including a causal method, a method of analysis and synthesis, a method of scientific abstraction.

\subsection{Ecological and economic security as a condition for the transition to a low-carbon growth model}

At the turn of the 21 st century, the world began to move towards a low-carbon growth model. The characteristic features of this model are: decarbonization, environmental standards, Industry 4.0, digitalization. 
The decarbonization of the global economy has created new threats and risks for companies and countries associated with the extraction and use of fossil fuels. Russia is among the countries most vulnerable to the risks associated with limiting greenhouse gas emissions. In the structure of the economy, a large share belongs to the production of energy-intensive products, the extraction and use of fossil fuels. International environmental ratings point to Russia's high environmental sustainability and its ability to adapt to climate change. At the same time, there is low-efficiency energy consumption and an extremely small share of renewable energy sources.

Russia signed the Paris Agreement and joined the decarbonization policy. However, the "rules of the game" are set by high-tech countries. Environmental standards are becoming a critical tool for decarbonization, through which EU countries competently isolate their market from competitors' products. The "green" agenda is becoming an environmental lever of protectionism.

At the same time, the fourth industrial revolution launched a new technological race, characterized by entry into the sixth technological structure (TS). According to Sergey Glazyev, «the world passes from the 5-th TS (which began in 1970-1980 on the basis of microprocessor technology, personal computers, the Internet, mobile communications, etc.) to the 6-th TS, which will complete the victory of the Information and Communication Revolution» [4]. Its main imperative will be "sustainable ecological "green" reproduction", as opposed to the "expanded innovative reproduction» of the fifth technological structure. The official authorities do not consider the scenario of a deep restructuring of the world economy. But the transformation has begun. The development of socio-economic systems at any level is directly dependent on compliance with environmental imperatives. Environmental and economic security is becoming an indispensable strategic priority of State policy.

The phenomenon of ecological and economic security is characterized by the state, conditions and factors that determine the trajectory of sustainable development at any level of socio-economic management: mega-, macro-, meso-, micro-, nano-. Each level has its own interests and priorities for sustainable development, related to the environment and the economy. Digitalization is becoming a mechanism for harmonizing environmental and economic policies at the macro- and meso- levels.

The transition to the sixth technological structure means "sustainable ecological "green" reproduction". Environmental and economic security acts as a condition, mechanism and factor for sustainable socio-economic development. In Russia, «the growing global challenges leading mankind to an environmental catastrophe» and «the creation of a system of environmental and economic security at various levels of government» is indicated in the Strategy for Scientific and Technological Development. The stability and progressive development of the regional economy depends on how organically it is integrated into the state economy as a relatively independent structure. Each Russian region has developed specific economic and environmental realities, which are projected to achieve regional and national environmental and economic security. At the same time, general trends can be identified that determine the conditions for sustainable development of each region during the transition to a new technological structure.

\subsection{The Russian region as a specific economic phenomenon and a subject of environmental and economic security}

In foreign scientific literature, economic and environmental security is considered as an element of national security or a component of economic policy. At the same time, there is no allocation of "economic" or "environmental" security at the level of any region or territory within the state. In Russia, increased attention to the problems of environmental 
and economic security is paid both at the state and regional levels. The Russian region is a specific phenomenon of a large multinational state. Some Russian regions are comparable in area to European states.

The term "region" is generally accepted to understand some holistic territory, do not have clear boundaries, but differs in the uniformity of certain characteristics:

- geographical: location of the territory, its size, population and other;

- production-function: specific types of activities prevailing in the territory;

- town planning: the type and character building area;

- social-historical: the historical social norms of communication and behavior that have developed in the assessed territory.

The Russian region is an integral socio-ecological and economic system that:

- it forms a multi-level administrative-territorial unit;

- it characterized by a unique economic trajectory of development based on material (land with natural resources; production and infrastructure), intangible (human and institutional capital) and impalpable (mental and reputational capital) factors of production;

- it has a unified administrative management, its own socio-economic interests and an established ecological and economic infrastructure.

Some Russian regions, whose products are harmonized with international quality standards, successfully compete in the global market. However, drastic measures aimed at reducing greenhouse gas emissions could be reduced to "NO" on their competitiveness. In the context of the climate agenda, the competitiveness of the region should be considered as a system of socio-ecological and economic relations determined by an individual set of resources, formed conditions and factors of regional reproduction that are inseparable from this territory and ensure its "sustainable ecological "green" reproduction».

\subsection{Conditions and factors of sustainable development of the region during the change of technological structure}

The regional economy has temporal and spatial characteristics. Spatial characteristics reflect its static (structural) properties: integrity( unity), hierarchy, heterogeneity and polarization. Time characteristics reflect dynamic (system) properties: self-organization, self-development, reproduction, interaction of subsystems, cyclical development (compression-expansion). The Russian regional development paradigm contains three basic positions:

- transition to sustainable development;

- inclusion of the region in global economic processes;

- the transition to a post-industrial model of development.

The key role in the process of scientific and technological development belongs to the industrial regions. They set the pace and models of modernization of production and consumption, transformation of technologies, change of ways of life. New information technologies have a very profound impact on the spatial organization of productive forces.

According to Russian scientists, " technological structures reflect the reproduction and development of productive forces and the production and technological systems that form them" [1]. The region is affected by macroeconomic and global development factors. In the context of changing technological patterns, regional development is undergoing transformations: from self-development as subsidized development to self-development as socially-oriented and coordinated development.

The current model of development of the Russian economy (with the current energy intensity and the level of extraction of fossil fuels) can only ensure a smooth stagnation of the economy relative to the current level, reducing the export potential to zero. Therefore, regions with a high potential for industrial development should reach growth rates 
comparable to the growth of the world economy, and commit to decarbonizing and "greening" the economy.

We have studied the genesis of the region's development in the context of changing technological structures. In Table 1, we have considered the following parameters of the region's evolution: the stages in the history of regional governance, the type of social reproduction, the methodological paradigm of regional policy, and the type of selfdevelopment of the region.

Table 1. The genesis of the region's Development in the context of changing technological structures (the traditional view).

\begin{tabular}{|c|c|c|c|c|}
\hline \multirow{2}{*}{$\begin{array}{l}\text { Properties } \\
\text { and } \\
\text { parameters }\end{array}$} & \multicolumn{4}{|c|}{ Technological structures } \\
\hline & III & IV & $\mathbf{V}$ & VI \\
\hline $\begin{array}{l}\text { Stages in the } \\
\text { history of } \\
\text { regional } \\
\text { governance }\end{array}$ & $\begin{array}{c}\text { from the late } \\
1920 \text { 's to the } \\
1940 \text { 's }\end{array}$ & 1950's-1970's & 1970's-1990's & $\begin{array}{l}\text { from the } 2000 \text { s to the } \\
\text { present }\end{array}$ \\
\hline $\begin{array}{c}\text { Type of } \\
\text { reproduction }\end{array}$ & $\begin{array}{c}\text { simple } \\
\text { reproduction }\end{array}$ & $\begin{array}{l}\text { expanded } \\
\text { reproduction }\end{array}$ & $\begin{array}{c}\text { enhanced } \\
\text { innovative } \\
\text { reproduction }\end{array}$ & $\begin{array}{l}\text { enhanced sustainable } \\
\text { "green" reproduction }\end{array}$ \\
\hline $\begin{array}{l}\text { Methodologic } \\
\text { al paradigm of } \\
\text { regional } \\
\text { policy }\end{array}$ & $\begin{array}{l}\text { emergency } \\
\text { assistance to } \\
\text { crisis regions }\end{array}$ & $\begin{array}{l}\text { interregional } \\
\text { redistribution } \\
\text { of economic } \\
\text { growth; } \\
\text { orientation to } \\
\text { balanced } \\
\text { regional } \\
\text { development, } \\
\text { creation of } \\
\text { growth poles }\end{array}$ & $\begin{array}{l}\text { neoclassical } \\
\text { and } \\
\text { technological } \\
\text { theories; } \\
\text { maximum use } \\
\text { of the natural } \\
\text { resource } \\
\text { potential of } \\
\text { the region }\end{array}$ & $\begin{array}{l}\text { balanced development } \\
\text { of regions; reduction of } \\
\text { the level of } \\
\text { differentiation of their } \\
\text { socio-economic } \\
\text { development; } \\
\text { introduction of } \\
\text { incentives for territorial } \\
\text { development }\end{array}$ \\
\hline $\begin{array}{l}\text { Type of self- } \\
\text { development } \\
\text { of the region }\end{array}$ & $\begin{array}{c}\text { self- } \\
\text { development } \\
\text { as self- } \\
\text { survival and } \\
\text { subsidized } \\
\text { development } \\
\end{array}$ & $\begin{array}{l}\text { self- } \\
\text { development } \\
\text { as a business } \\
\text { development }\end{array}$ & $\begin{array}{c}\text { self- } \\
\text { development } \\
\text { as a socially- } \\
\text { oriented and } \\
\text { coordinated } \\
\text { development }\end{array}$ & $\begin{array}{l}\text { self-development as a } \\
\text { sustainable socio- } \\
\text { ecological and } \\
\text { economic development }\end{array}$ \\
\hline
\end{tabular}

We made the following conclusions. In the sixth technological structure, the region will develop according to the type of "self-development as a sustainable socio-ecological and economic development". Regional reproduction will host on the features of "extended sustainable" green "reproduction". The region becomes a specific phenomenon. It is important to determine the place of the region in the economic future of the national economy and the potential of its competitiveness.

We know that the requirements of "green" standards will affect all levels of the national economy, having a negative impact on industrial regions. The priority of the state is to coordinate the federal and regional assessment of global, national and regional trends, challenges, threats, "windows of opportunity" and their consequences. In the new technological structure, the Russian regions should form a system of ecological and economic security. We believe that this is objectively due to the evolution of regional development.

In Table 2, we have considered the parameters of the region's evolution, which are determined by the climate agenda. 
Table 2. The genesis of the region's Development in the context of changing technological structures (the view from the perspective of the climate agenda).

\begin{tabular}{|c|c|c|c|c|}
\hline \multirow{2}{*}{$\begin{array}{c}\text { Properties and } \\
\text { parameters }\end{array}$} & \multicolumn{4}{|c|}{ Technological structures } \\
\hline & III & IV & $\mathbf{V}$ & VI \\
\hline $\begin{array}{l}\text { The essence of } \\
\text { the region in the } \\
\text { economic space }\end{array}$ & $\begin{array}{l}\text { a region is } \\
\text { a factor of } \\
\text { favorable } \\
\text { business } \\
\text { conduct }\end{array}$ & $\begin{array}{c}\text { a region is a } \\
\text { subsystem and } \\
\text { a factor of the } \\
\text { national } \\
\text { economy } \\
\text { development }\end{array}$ & $\begin{array}{c}\text { a region is a } \\
\text { phenomenon of } \\
\text { a market } \\
\text { economy and a } \\
\text { concentration of } \\
\text { capital }\end{array}$ & $\begin{array}{l}\text { a region is a subsystem } \\
\text { of the national } \\
\text { economy and an } \\
\text { independent subject of } \\
\text { economic relations, } \\
\text { including international } \\
\text { economic relations }\end{array}$ \\
\hline Impact factors & $\begin{array}{l}\text { micro- } \\
\text { economics } \\
\text { factors }\end{array}$ & $\begin{array}{l}\text { meso- } \\
\text { economics } \\
\text { factors }\end{array}$ & $\begin{array}{l}\text { macro- } \\
\text { economics } \\
\text { factors }\end{array}$ & global factors \\
\hline $\begin{array}{l}\text { Level of } \\
\text { concentration of } \\
\text { economic } \\
\text { interests }\end{array}$ & $\begin{array}{l}\text { interests } \\
\text { of the } \\
\text { company } \\
\text { owner }\end{array}$ & $\begin{array}{l}\text { interests of } \\
\text { corporations } \\
\text { and } \\
\text { enterprises }\end{array}$ & $\begin{array}{l}\text { the interests of } \\
\text { transnational } \\
\text { corporations, } \\
\text { industries } \\
\text { holdings }\end{array}$ & $\begin{array}{l}\text { interests of the national } \\
\text { economy and the } \\
\text { individual region }\end{array}$ \\
\hline $\begin{array}{l}\text { Basic resources } \\
\text { for economic } \\
\text { development }\end{array}$ & $\begin{array}{l}\text { climate, } \\
\text { natural } \\
\text { resources, } \\
\text { and } \\
\text { human } \\
\text { resources }\end{array}$ & $\begin{array}{c}\text { raw materials, } \\
\text { material and } \\
\text { technical } \\
\text { resources }\end{array}$ & $\begin{array}{l}\text { human capital, } \\
\text { information } \\
\text { resources }\end{array}$ & $\begin{array}{l}\text { space and time } \\
\text { resources }\end{array}$ \\
\hline $\begin{array}{l}\text { Specific } \\
\text { resources }\end{array}$ & $\begin{array}{l}\text { governme } \\
\text { nt grants } \\
\text { and } \\
\text { targeted } \\
\text { financing }\end{array}$ & $\begin{array}{l}\text { credit and } \\
\text { financial } \\
\text { resources }\end{array}$ & $\begin{array}{l}\text { technological } \\
\text { and } \\
\text { infrastructural } \\
\text { potential }\end{array}$ & $\begin{array}{c}\text { innovation } \\
\text { infrastructure, } \\
\text { intellectual capital, the } \\
\text { health of the nation }\end{array}$ \\
\hline $\begin{array}{l}\text { Risks and } \\
\text { threats }\end{array}$ & $\begin{array}{r}\text { regional } \\
\text { problems p } \\
\text { affect busi } \\
\text { there is no } \\
\text { component } \\
\text { pr }\end{array}$ & $\begin{array}{l}\text { nvironmental } \\
\text { actically do not } \\
\text { ess parameters; } \\
\text { environmental } \\
n \text { technological } \\
\text { cesses }\end{array}$ & $\begin{array}{l}\text { strengthening } \\
\text { regional } \\
\text { differentiation } \\
\text { in terms of } \\
\text { environmental } \\
\text { and economic } \\
\text { security } \\
\text { and quality of } \\
\text { life }\end{array}$ & $\begin{array}{l}\text { permanently adjusted } \\
\text { environmental risks; } \\
\text { environmental factors } \\
\text { become an } \\
\text { independent factor in } \\
\text { the reproduction } \\
\text { process; negative } \\
\text { impact of } \\
\text { environmental } \\
\text { externalities on } \\
\text { individual reproduction }\end{array}$ \\
\hline
\end{tabular}

Based on the data provided, the following conclusion can be drawn.

Almost until the end of the XX century, the development of ecological and economic infrastructure is mainly inertial. The Fourth Industrial Revolution launched a new technological race, characterized by the entry into the sixth technological structure. "Expanded sustainable green reproduction" has become the main imperative of development, as opposed to "expanded innovative reproduction " of the fifth technological structure. The climate agenda changes the conditions for the socio-economic development and competitiveness of the region. Uncharacteristic dynamics or exceeding the limit of economic growth can have serious environmental consequences. The region may lose opportunities for sustainable development. The environmental and economic interests of the individual region and the national economy must meet the requirements of consistency and consistency.

Based on the above, we give the following description of the concept of "ecological and 
economic security of the region".

The ecological and economic security of the region is characterized by the following content:

- conducting its own economic policy without compromising regional environmental interests;

- the ability to respond adaptively to macroeconomic and geopolitical changes;

- the ability to implement large-scale events and major projects without the help of the federal center.

\section{Discussion and Acknowledgement}

In foreign scientific literature, economic security is considered as an element of national security or a component of economic policy. "Economic" or "environmental" security at the level of any region or territory within the state is practically not studied. The transition to the sixth technological structure and the climate agenda presuppose the harmonization of the economic and environmental components of regional development. This implies a broad scientific discussion. The authors will be grateful for feedback and critical comments on the topic.

\section{Conclusions}

The study of the evolution of regional development allowed us to confirm the hypothesis of the region as a specific phenomenon of the sixth technological structure. The origins of sustainable socio-ecological and economic development of the region lie in the sphere of ecological and economic security. It should be ensured through regional economic policies. It is necessary to coordinate the priorities of spatial and scientific and technological development with unconditional respect for regional environmental interests. The success of the country and the regions will depend on the speed of the necessary transformations. To do this, it is necessary to rebuild the structure of production and public institutions.

\section{References}

1. V.S. Bochko, Economy of region 1(41), 39-52 (2015) DOI: 10.17059/2015-1-4

2. S.D. Bodrunov, Journal of the Ural State University of Economics 20(1), 5-12 (2019) DOI: $10.29141 / 2073-1019-2019-20-1-1$

3. G. Clar, B. Sautter, Journal of the Knowledge Economy 5(1), 156-180 (2014) DOI: 10.1007/s13132-014-0180-0.

4. S.Yu. Glazyev, A.E. Ajvazov, V.A. Belikov, Economy of Region 14(1), 1-12 (2018) doi 10.17059/2018-1-1

5. E. Kampragou, S. Apostolaki, E. Manoli, J. Froebrich, D. Assimacopoulos, Environmental Science \& Policy 14(7), 815-824 (2011) DOI: 10.1016/j.envsci.2011.04.001.

6. E.A. Kolomak, Spatial Economics 15(4), 85-106 (2019) DOI: 10.14530/ se.2019.4.085-106

7. P.R. Krugman, Geography and trade (Cambridge, MIT Press, 1991)

8. Yu.G. Lavrikova, A.V. Suvorova, Economy of region 16(4), 1017-1030 (2020) https://doi.org/10.17059/ ekon.reg.2020-4-1.

9. G. Medve-Balint, Studies in Comparative International Development 53(2), 218-238 
(2018) DOI: $10.1007 / \mathrm{s} 12116-018-9265-2$

10. W.A. Oates, Empirica 25(1), 1-13 (1998) DOI: 10.1023/A:1006832604045

11. C. Perez, Cambridge Journal of Economics 34(1), 185-202 (2009)

12. D. Rodrik, Search of Prosperity: Analytic Narratives on Economic Growth (Princeton University Press, Princeton, NJ, 2003)

13. V. Rodriguez, A. Soeparwata, Journal of the Knowledge Economy 6(2), 228-249 (2015) DOI: 10.1007/s11192-011-0603-7.

14. H. Tolkki, A. Haveri, J. Airaksinen, E. Valkonen, Public Organization Review 11(4), 313-333 (2011) 